\title{
PEMBERDAYAAN PANTI ASUHAN MELALUI PENGELOLAAN KEGIATAN PADA BIDANG LINGKUNGAN DAN PERTANIAN DI PANTI ASUHAN PUTRI MUHAMMADIYAH PAKEM YOGYAKARTA
}

\author{
Siti Fatimah ${ }^{1 *}$, M. Heri Zulfiar ${ }^{2}$, Firman Mansir ${ }^{3}$ \\ 1,2,3 Universitas Muhammadiyah Yogyakarta \\ *E-mail: firmanmansir@umy.ac.id
}

\begin{abstract}
ABSTRAK
Situasi pandemi saat ini merupakan situasi yang harus dihadapi oleh seluruh masyarakat dunia, termasuk masyarakat Indonesia. Ketahanan pangan merupakan salah satu bidang kehidupan yang dalam masa pandemi Covid-19 ini harus tetap dipertahankan. Dibutuhkan pemberdayaan masyarakat yang baru guna pemenuhan kebutuhan pangan, salah satunya adalah kebutuhan akan sayur dan protein. Upaya pihak panti asuhan untuk meningkatkan keterampilan anak-anak panti asuhan terkendala kurangnya keterampilan budidaya pertanian pada lahan sempit serta minimnya keterampilan mengolah produk pangan yang bernilai ekonomis. Tujuan dari penerapan kegiatan lingkungan di bidang pertanian ini adalah untuk mengatasi masalah tersebut yaitu mengembangkan sistem pertanian dengan menggunakan akuaponik dan hidroponik yang mengarah untuk menghasilkan produk pertanian berupa sayur-sayuran dengan sistem hidroponik. Sistem pertanian hasil modifikasi berupa pembudidayaan ikan sederhana dengan menggabungkan sistem pertanian hidroponik dengan budidaya akuakultur. Hasil dari pengabdian ini yaitu panti asuhan khususnya anak-anak asuh panti asuhan mendapatkan keterampilan dan pengetahuan seputar budidaya yang mudah dilakukan dan dapat menghasilkan sayur.
\end{abstract}

Kata kunci: Pemberdayaan, Pertanian, Budidaya, Hidroponik

\section{EMPOWERMENT OF ORGANIZATIONS THROUGH MANAGEMENT OF ENVIRONMENTAL AND AGRICULTURAL ACTIVITIES IN PRINCESS MUHAMMADIYAH ORPHANAGE PAKEM YOGYAKARTA}

\begin{abstract}
The current pandemic situation is a situation that must be faced by the entire world community, including the people of Indonesia. Food security is one area of life that during this Covid-19 pandemic must be maintained. New community empowerment is needed to fulfill food needs, one of which is the need for vegetables and protein. The efforts of the orphanage to improve the skills of the orphanage children are constrained by the lack of skills. In agricultural cultivation on narrow land and the lack of skills in processing food products of economic value. The purpose of implementing environmental activities in agriculture is to overcome these problems. Namely developing agricultural systems using aquaponics and hydroponics that led to producing agricultural products in the form of vegetables with a hydroponic system. The modified farming system is in the form of simple fish cultivation by combining hydroponic farming systems with aquaculture cultivation. The result of this service is that orphanages, especially foster children, get skills and knowledge about cultivation that is easy to do and can produce vegetables.
\end{abstract}

Keywords: Empowerment, Agriculture, Cultivation, Hydroponics

\section{PENDAHULUAN}

Pandemi yang disebabkan oleh Covid-19 telah merebak di Indonesia. Tantangan utama yang dihadapi adalah keharusan untuk tetap menjaga jarak antarindividu dan mengurangi aktivitas diluar rumah untuk memutus rantai persebaran virus. Di sisi lain, perlunya stok pemenuhan kebutuhan akan pangan bagi pihak panti asuhan harus tetap tersedia dalam skala terkecil yaitu skala rumah tangga. 
Dengan mengusung ketahanan pangan di masa pandemi ini, maka dibutuhkanlah pemberdayaan panti asuhan yang baru dalam pemenuhan kebutuhan pangan, yang salah satunya adalah kebutuhan akan sayur dan protein. Pemberdayaan adalah keadaan yang terjadi atau hal-hal yang dilakukan di lingkungan masyarakat dengan upaya membangun pembangunan yang bertumpu pada masyarakat itu sendiri.

Salah satu solusi untuk memenuhi kebutuhan sayur dalam fase adaptasi kebiasaan baru ini adalah dengan menerapkan sistem pengelolaan kegiatan di bidang lingkungan dan pertanian bagi panti asuhan untuk pertanian dan usaha pembudidayaan ikan. Sistem pengelolaan kegiatan di bidang lingkungan pertanian atau penerapan sistem aquaponik dan hidroponik merupakan sebuah modifikasi pembudidayaan ikan sederhana dengan menggabungkan sistem pertanian hidroponik dengan budidaya perikanan air tawar. Sistem ini lebih dikenal dengan nama aquaponik yang sudah sangat berkembang yang secara luas dipraktikan oleh masyarakat sebagai upaya pemenuhan sayuran dan sumber protein sebagai bahan pangan sehari - hari. Secara sederhana, aquaponik dapat digambarkan sebagai penggabungan antara sistem budidaya akuakultur (budidaya ikan) dengan hidroponik (budidaya tanaman/ sayuran tanpa media tanah).

Sistem ini mengadopsi sistem ekologi pada lingkungan alamiah, dimana terdapat hubungan simbiosis mutualisme antara ikan dan tanaman. Pengelolaan kegiatan lingkungan pertanian di panti asuhan adalah cara alternatif untuk menanam sayuran sekaligus membudidayakan ikan dalam satu wadah. Tanaman sayur membutuhkan nutrisi untuk tumbuh yang disuplai dari kotoran ikan sebagai sumber unsur hara. Keuntungan bagi ikan adalah memperoleh filter vegetasi alami yang akan mengurai zat racun sekaligus menyuplai oksigen bagi ikan. Dengan hubungan timbal balik ini akan menjadi simbiosis yang saling menguntungkan. Metode ini memiliki keunggulan jika dibandingkan dengan sistem konvensional, yang salah satunya adalah penggunaan air sebagai pengganti media tanah dalam praktiknya, sehingga lebih praktis untuk diterapkan. Dengan latar belakang mata pencaharian mayoritas penduduk sebagai petani, Pemberdayaan panti asuhan melalui pelatihan sistem pengelolaan kegiatan lingkungan pertanian melalui sistem aquaponik dan hidproponik diharapkan dapat menjadi cara alternatif untuk dikembangkan dengan memadukan antara sistem pertanian hidroponik dengan sistem akuakultur guna meningkatkan sumber daya manusia sekaligus menumbuhkan kesadaran, kemauan, dan kemampuan masyarakat dalam mengenali dan meningkatkan kesejahteraan Panti Asuhan Putri Muhammadiyah Pakem untuk pemenuhan kebutuhan pangan skala rumah tangga dan dapat dijadikan opsi untuk penambahan penghasilan.

\section{METODE}

Kegiatan pengabdian masyarakat ini, kami memilih untuk menggunakan metode kepada masyarakat dengan kegiatan sosialisasi, sehingga dibutuhkan sebuah metode yang tepat sasaran agar pelaksanaan berjalan baik dan tujuan tercapai seperti apa yang diharapkan. Karena itu yang dilakukan adalah:

a. Observasi dan wawancara

Metode ini dilakukan dengan masyarakat dan para anak panti asuhan agar tujuan kegiatan pengabdian bisa difahami dengan baik

b. Ceramah dan Diskusi

Metode ini penting dan tidak bisa dilepaskan pada pengabdian masyarakat di panti asuhan, karena itu metode ini dipilih agar para pegabdi sebagai pembicara dapat dengan mudah menyajikan konsep penting mengenai pertanian agar bertujuan dapat dipahami serta dengan mudah para peserta sosialisasi menangkap apa yang disampaikan

c. Demonstrasi dan Praktik

Metode ini dapat menunjukkan proses penggunaan pertanian dalam penanaman sayuran sebagai kebutuhan sehari-hari yang tidak bisa ditinggalkan. Karena itu kemudian, dengan ini semua peserta dapat diajak untuk aktif melakukannya secara langsung dan dapat dipantau, sehingga apa yang disampaikan dengan mudah langsung dilakukan oleh peserta atau anak panti asuhan. 


\section{HASIL DAN PEMBAHASAN}

Kegiatan Pengelolaan di bidang lingkungan dan pertanian ini diawali dengan observasi yang dilakukan untuk mendapatkan informasi mengenai potensi dari Panti Auhan Putri Muhammdiyah Pakem dan hal yang dapat dikembangkan. Proses observasi dilakukan dengan mengunjungi Kepala Panti Asuan dan melakukan wawancara sekaligus meminta izin untuk melakukan kegiatan pengabdian di Panti Asuhan Putri Muhammadiyah Pakem. Setelah mendapatkan izin dari kepala panti kemudian melakukan penentuan waktu dan lokasi pelaksanaan pengelolaan dan pelatihan. Metode yang digunakan dalam kegiatan ini yaitu dengan metode sosialisasi secara langsung. Di mana dalam pelaksanaannya terdapat beberapa tahapan, yaitu : tahap persiapan, tahap sosialisai, tahap praktik lapangan dan tahap evaluasi kegiatan.

1. Tahap persiapan

Pada tahap ini hal yang dilakukan yaitu pertama, melakukan survei dan komunikasi kepada Kepala Panti Asuhan Pakem dan menanyakan seputar kegiatan pertanian di Panti Asuhan Putri Muhammdiyah Pakem, setelah itu melakukan persiapan rancangan kegiatan.

2. Tahap Sosialisasi

Sosialisasi dilakukan dengan maksud untuk memaparkan rincian dari kegiatan pengelolaan lahan panti asuhan di bidang pertanian yang telah dirancang untuk mengenalkan sekaligus menambah pengetahuan anak - anak panti asuhan. Sosialisasi dilakukan secara online.

3. Tahap Praktik Langsung

Pada tahap ini anak - anak panti asuhan melakukan praktik langsung pengelolaan lahan panti asuhan di bidang pertanian menggunakan sistem aquaponik dan hidroponik yang didampingi oleh mahasiswa KKN.

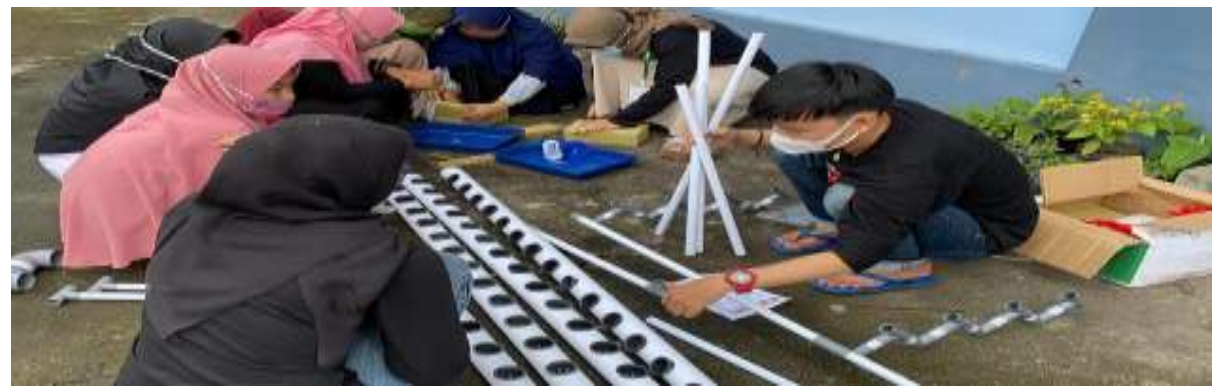

Gambar 1.1 : Pemasangan pipa hidroponik

4. Tahap Evaluasi

Setelah selesai melakukan praktik secara langsung, anak anak panti akan mendengarkan penjelasan materi dan dapat bertanya seputar pengelolaan pertanian dengan sistem aquponik dan hidroponik. Evaluasi awal dilakukan oleh tim pelaksana dalam dua hal kegiatan, yaitu:

1) Kegiatan inti pada saat peserta menerima materi pelatihan dan praktik pembuatan pengelolaan pertanian dengan sistem aquaponik dan hidroponik.

2) Diluar kegiatan inti, yaitu meninjau kualitas sayuran secara hidroponik yang dihasilkan setelah tim pelaksana melaksanakan kegiatan pengabdian kepada masyarakat serta memberi arahan bagaimana memulai wirausaha mandiri. 


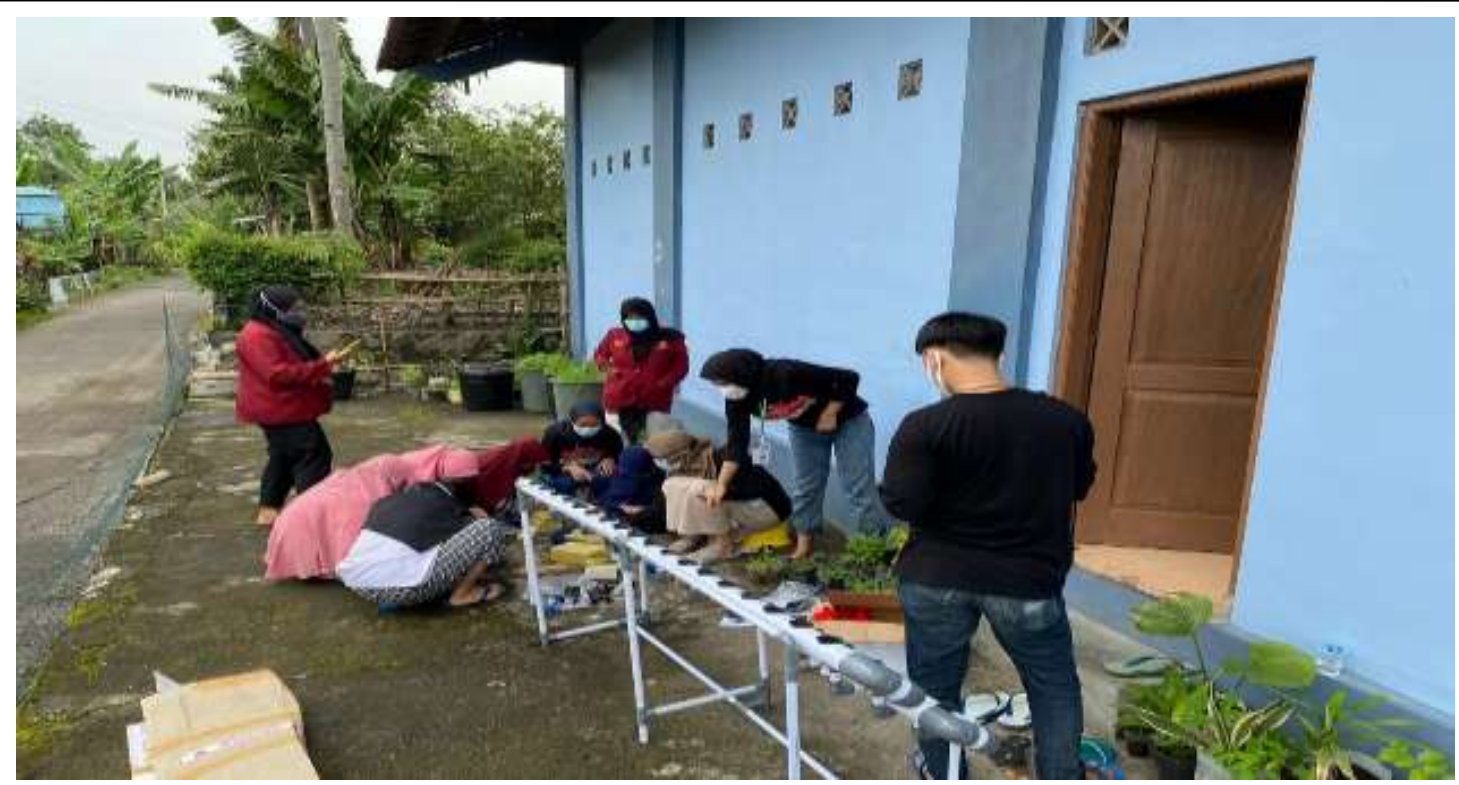

Gambar 1.2 : Memasukan benih kangkung ke dalam pipa hidroponik

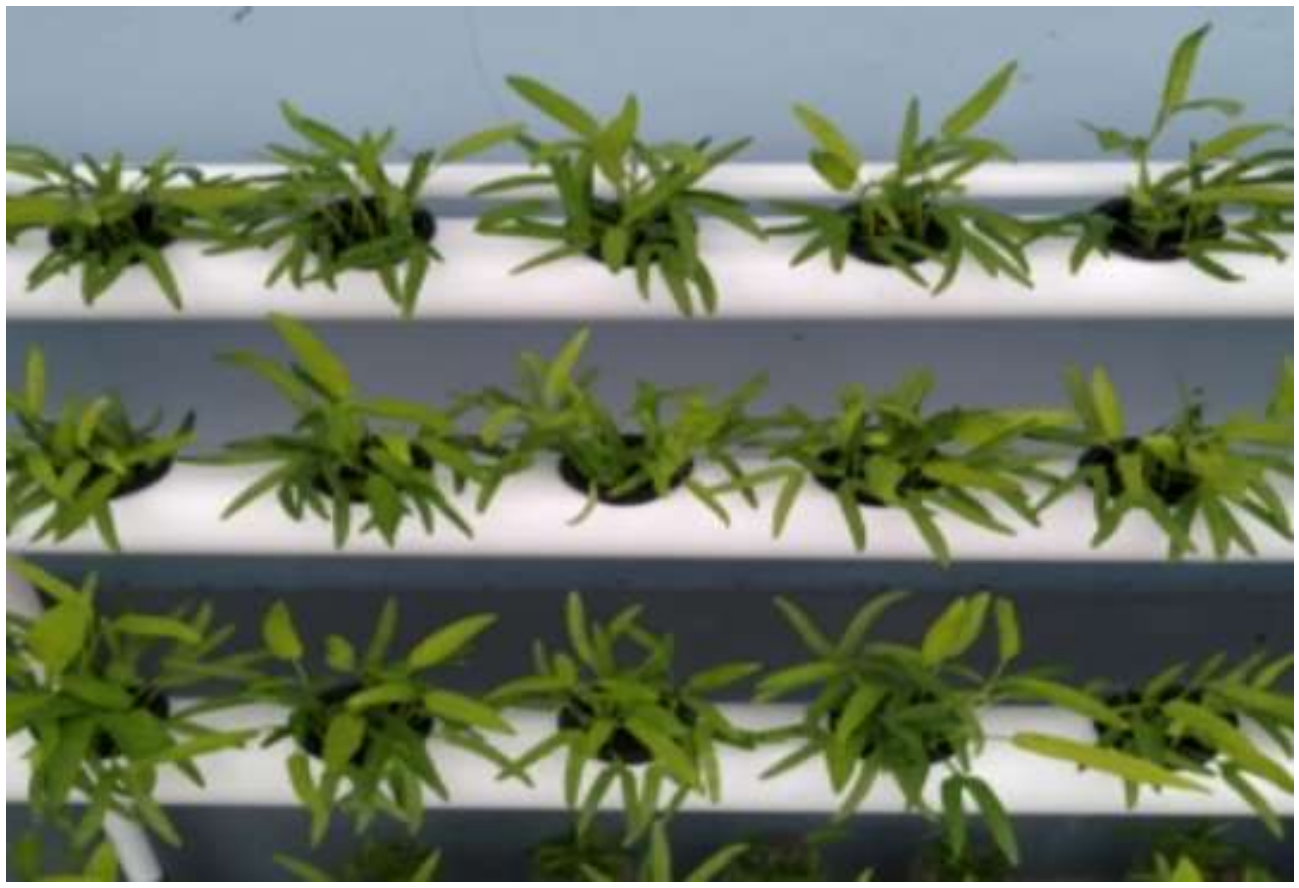

Gambar 1.3 : Petumbuhan kangkung di dalam pipa hidroponik

Tim KKN Kelompok 008 menjelaskan kepada masyarakat bahwa untuk penggunaan Hidroponik dapat dilaksanakan lebih mudah dan sederhana, karena tidak memerlukan perawatan yang begitu ekstra. Selain itu, penggunaan pipa hidroponik dapat lebih menghemat biaya dan hasil yang diperoleh saat panen. Dari hasil diskusi setelah pemaparan maka diputuskan bahwa pelatihan yang akan dilakukan yaitu hidroponik. Kegiatan pelatihan pengeolaan di bidang pertanian dengan sistem hidroponik diawali dengan sedikit penyampaian materi dari Tim KKN Kelompok 008, kemudian anak-anak panti dibagi dalam beberapa kelompok kecil untuk mulai mempraktekan seperti 
BAKTI BANUA : Jurnal Pengabdian Kepada Masyarakat

Volume 2 No. 22021

e-ISSN : 2722-3736

p-ISSN : 2722-7529

https://ejurnal.stimi-bjm.ac.id/index.php/BBJM/

mempersiapkan alat dan bahan. Setiap anak panti dan pengurus panti kemudian mencoba untuk mempraktekannya dan memasukkan benih kangkung ke dalam pipa hidroponik yang sudah dibeli dari TIM KKN 008 saat dalam tahap persiapan. Dalam pelatihan pengelolaan dibidang pertanian dengan sistem hidroponik ini dihasilkan satu paket pipa hidroponik besar yang telah diisi dengan benih kangkung.

Kegiatan pengabdian panti asuhan ini dilanjutkan dengan kegiatan monitoring atau pengawasan terhadap pengelolaan di bidang pertanian dengan sistem hidroponik yang telah diberikan kepada pihak panti asuhan. Terdapat beberapa kendala yang ditemukan yaitu, lahan untuk penanaman hidroponik yang kurang memadai dan air pada pipa hidroponik cepat surut, sehingga tanaman kangkung kurang subur. Namun, hal tersebut dapat diatasi dengan lebih memperhatikan air yang terdapat di dalam pipa hidroponik agar tidak cepat surut. Sehingga pada minggu berikutnya dapat dilakukan pemanenan sayuran kangkong berikutnya dapat dilakukan pemanenan sayuran kangkung. 

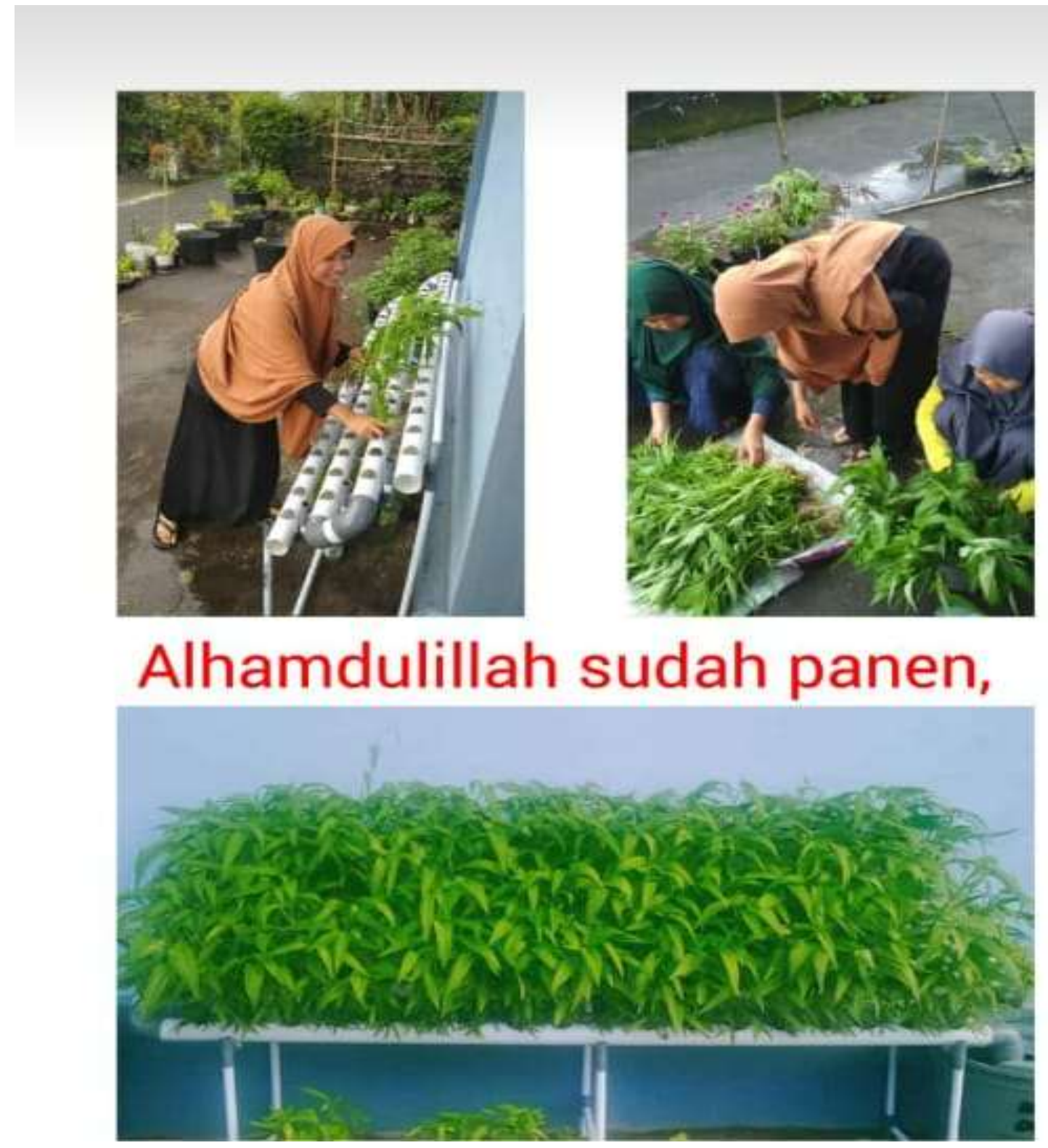

Gambar 1.4 : Hasil panen dari penenaman kangkung dengan hidroponik

\section{KESIMPULAN}

Pemberdayaan Panti Asuhan melalui pengelolaan kegiatan di bidang lingkungan dan pertanian di Panti Asuhan Putri Muhammadiyah Pakem Yogyakarta yang dilakukan oleh TIM KKN Persyarikatan IT 008 dengan sistem hidroponik ini di lakukan dengan beberapa tahapan yaitu tahapan persiapan, tahap sosialisai, tahap praktik lapangan dan tahap evaluasi kegiatan. Pelatihan pengelolaan di bidang pertanian ini cocok dan mampu dilakukan oleh anak-anak panti dan pengurus panti asuhan. Hasil dari pelatihan pengelolaan kegiatan di bidang pertanian ini adalah anak - anak panti asuhan mampu memahami cara bertanam dengan sistem hidroponik ini serta mampu mempraktekkan secara mandiri. Selain itu, penggunaan pipa hidroponik ini dapat lebih menghemat biaya dan hasil yang diperoleh saat panen mendapatkan sayur kangkung yang banyak. Dalam tiga minggu telah dapat 
dilakukan pemanenan sayuran. Dari TIM KKN 008 mengharapkan dengan adanya pengelolaan kegiatan di bidang lingkungan dan pertanian dengan sistem hidroponik ini, Panti Asuhan Putri Muhammadiyah Pakem dapat memenuhi kebutuhan makan untuk sehari - hari dan juga dapat di jadikan opsi untuk berusaha.

\section{DAFTAR PUSTAKA}

Balai Pengkajian Teknologi Pertanian (BPTP). 2016. Teknologi Aquaponik Mendukung Pengembangan Urban Farming.

Edwardi. 2017. Inilah Manfaat Bercocok Tanam Hidroponik. Bangka Pos. Retrieved from https://bangka.tribunnews.com/2017/04/01/inilah-manfaat-bercocok-tanamhidroponik . diakses tanggal 2 Juli 2019.

Sulistyawati, dkk. 2019. Pendampingan Pembuatan Sistem Hidroponik dan Pengolahan

Sampah Organik. Jurnal Pengabdian dan Pemberdayaan Masyarakat. Volume 3 (1) : 77-82.

Wijayanto, H. 2019. Pemberdayaan Kelompok Tani Desa Jatimalang, Kabupaten Pacitan melalui Pelatihan Pembuatan Pupuk Organik. Agrokreatif Jurnal Ilmiah Pengabdian Kepada Masyarakat. Vol 5 (2) : 109-114.

Marsela, F. (2018). Sistem Akuaponik Dengan Limbah Kolam Ikan Lele Untuk Memproduksi Sayuran Organik. Skripsi. Fakultas Pertanian. Universitas Lampung. Bandar Lampung 